\title{
SEISMIC VULNERABILITY ASSESSMENT OF REINFORCED CONCRETE STRUCTURES IN KURDISTAN REGION-IRAQ
}

\author{
MAND ASKAR ${ }^{1, *}$, KAMIRAN ABDUKA $^{* *}$ and LAWEND ASKAR ${ }^{* * *}$ \\ * Technical College of Engineering, Duhok Polytechnic University, Duhok, Kurdistan Region-Iraq \\ *Faculty of Science, Engineering and Technology, Swinburne University of Technology, Melbourne-Australia \\ ${ }^{* * *}$ Technical College of Engineering, Duhok Polytechnic University, Duhok- Kurdistan Region-Iraq
}

(Accepted for Publication: December 8, 2020)

\begin{abstract}
Earthquakes are one of the most destructive natural disasters that cause losses of life, damage to infrastructure and economic issues. Therefore, seismic risk assessment is essential for disaster mitigation, disaster management, and emergency preparedness. Seismic vulnerability is one of the major factors for evaluating the risk of earthquakes on reinforced concrete (RC) buildings. Seismic vulnerable RC buildings are buildings located in a seismic region and either designed with an outdated design code or designed without consideration for seismic activity. In the Kurdistan region of Iraq, most of the existing RC buildings do not meet the typical current seismic standard requirements as the region was expected as non-seismic region and followed the Iraqi seismic zone which considered as a low seismic region, therefore these type of buildings is expected to suffer extensive damage during strong earthquakes. Vulnerable RC buildings should be assessed in order to prevent future damage and new designed buildings need to meet such codes. Previous studies, conducted assessment of four to six stories structures in order to evaluate seismicity and to increase ductility of the evaluated structures based on member size. In this research, an existing 8-storey RC building, located in Duhok governorate- Kurdistan region of Iraq, is redesigned and evaluated. SeismoStruct V6.5 software was utilized for the purpose of simulating ductility and detailing for the existing structure using pushover analysis. The ductility of the existing and the proposed redesigned buildings then evaluated by obtaining inter-story drift and displacement based on capacity curve. The original design is further evaluated in terms of reinforcement ratio and detailing by redesigning the existing building in accordance with the ACI code 318, 2014 and using ETABS software version 9.7 for analysing. Nonlinear static pushover analysis is used for seismic performance evaluation. Inelastic static analysis procedures include capacity spectrum method and displacement coefficient method. The structure is then analyzed to observe the yielding of the members and the adequacy of the structural strength. The extent of damage experienced by the structure at the target displacement represents the damage that would be experienced by the building when it is subjected to an earthquake. As a conclusion, the redesigned structure showed $30 \%$ increasing in displacement when loaded in $x$ direction based on both ultimate and calculated base shear while the increase in displacement was around $10 \%$ when loaded in the y-direction. This displacement increase led into improving the ductility in the redesigned structure.
\end{abstract}

KEYWORDS : Seismic assessment; non-linear static pushover analysis; RC buildings; target displacement; capacity curve.

\section{INTRODUCTION}

$\mathbf{E}$ arthquakes can cause devastating damage to buildings, bridges and in many cases cause death. However, many reinforced concrete (RC) structures, which represent a large proportion of the building stock in many countries all over the world, do not meet the current seismic requirements and suffer extensive damage during earthquakes (RAJU 2012). Thus, a seismic assessment of vulnerable $\mathrm{RC}$ buildings is mandatory in any area that has moderate or high seismic activity. Many existing $\mathrm{RC}$ buildings in medium to high seismic region were designed according to recently outdated codes. In low seismic regions, most existing buildings were designed without taking into account seismic criteria, which means they are gravity load designed (GLD). Both types of existing reinforced concrete have often displayed unsatisfactory seismic behaviour because they do not have sufficient resistance to seismic activities. Egypt is an example for that, according to (EL-KHOLY 2012), most of the

mand.askar@edu.dpu.krd, kabdouka@swin.edu.au, lawend.kamal@dpu.edu.krd ${ }^{1}$ Corresponding author: ${ }^{1}$ Technical College of Engineering, Duhok Polytechnic University, Duhok- Kurdistan Region 
buildings in Egypt were gravity load designed until 1992, when Egypt was hit by an earthquake. Despite the fact that the earthquake was not classified in the strongest category, it caused damage and casualties all over the country. The collapse of vulnerable buildings in the last century because of earthquakes in many countries worldwide caused thousands of casualties, cost millions of dollars. Another example is Halabjah earthquake in July 2018 in Sulaymaniyah-Iraq with 7.3 magnitude. Therefore, this study aims to assess RC structures in term of seismicity behaviour with according to ACI standard.

\section{LITERATURE REVIEW}

The validity, applicability, and accuracy of the inelastic static pushover analysis in predicting the seismic response of RC buildings were investigated by (Castaldo 2017) and (KRAWINKLER 1998). They validated pushover analysis by adopting inelastic static pushover analysis for predicting seismic performance in existing RC buildings. A fourstorey steel structure building was modelled. The study investigated the target displacement of the structure at the roof using a variety of load patterns. Similar to (MWAFY 2001), the study indicated that the pushover analysis is an adequate analysis tool for low and moderate-rise structures. During severe earthquakes, the pushover analysis gives insight into the structural aspects that control performance. With structures that vibrate primarily in the fundamental mode, the pushover analysis provides adequate estimates of global, local inelastic, and deformation demands. It also exposes the weaknesses that can be hidden in an elastic analysis such as story mechanisms, excessive deformation demands, strength irregularities and overloads on potentially brittle elements such as columns and connections. Furthermore, pushover analysis can be performed as force controlled or displacement controlled. In force controlled pushover method, load combination is applied as specified. It is recommended that force-controlled procedure to be used when the load is known such as gravity load (AHMED 2013).

Seismic response of the structures can be obtained by focusing on two damage factors, inter-storey drift and the ductility demand based on capacity curve (Figure1) (MASI 2012). A total of 216 building classes were defined in this study by simulating some factors which were practiced at the time of construction such as: number of storeys, infill presence and position, plan dimensions, external beam stiffness and concrete strength. Results show that the height of the structure and the distribution of the infill are the most significant, parameters that effect the performance of the structure. The only drawback is that it did not take into account height

irregularities.

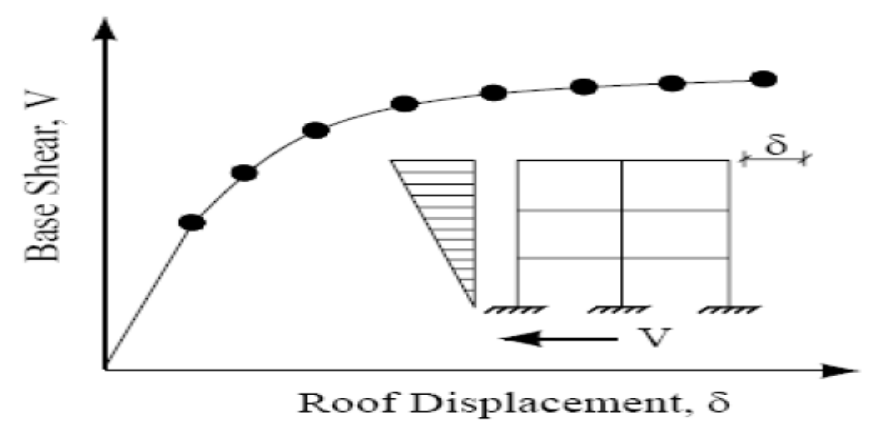

Figure 1: Capacity curve [6]

According to (EL-KHOLY 2012) and (REPAPIS 2006), existing RC buildings have higher over-strength compared to newly designed buildings, which have very low ductility. A low ductility capacity is a significant factor for resisting seismic activity. It has been found that buildings with the same configuration but with perimeter infill walls show considerably better stiffness and lateral resistance. However, these types of configuration show further reduction in the ductility and would be vulnerable to seismicity when such structures

mand.askar@edu.dpu.krd, kabdouka@swin.edu.au, lawend.kamal@dpu.edu.krd

${ }^{1}$ Corresponding author: ${ }^{1}$ Technical College of Engineering, Duhok Polytechnic University, 
have irregularities in height specifically in first storey.

Irregular structures have limited lateral resistance and are susceptible to storey mechanisms during earthquake loading. To avoid sudden changes in the overall strength or stiffness at any particular level, the vertical regularity check is essential (ATHANASSIADOU 2008), (RAJEEV 2012). The effects of vertical irregularity on the median values of storey drifts and floor displacements were studied by (CHINTANAPAKDEE 2004). Modal pushover analysis (MPA) was used to obtain the median and dispersion values of the ratio of storey drift demands. They established two main results. Firstly, the accuracy of the MPA procedure does not deteriorate, regardless of the location of irregularity in stiffness, strength, or stiffness and strength. Secondly, MPA is able to accurately identify stories with the largest drift demands and detect critical storeys.

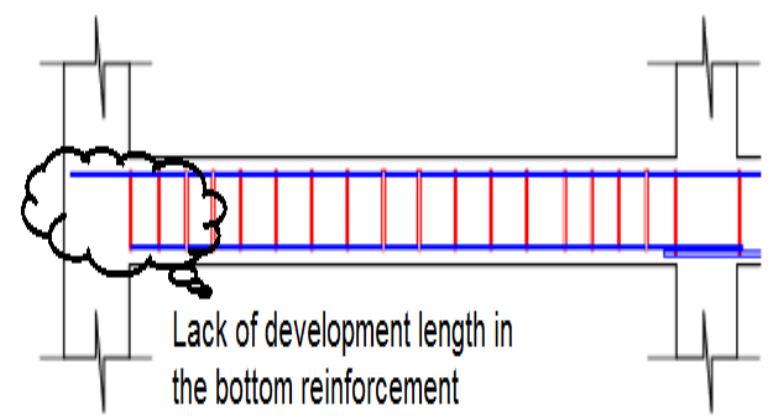

\section{CASE STUDY \\ 3.1 Existing Building}

An existing reinforced concrete structure was assessed in relation to current design practices and construction detailing practices in the Kurdistan region, and then seismic analysis of those buildings using the ASCE 41-06 2007 was conducted.

The selected building is located in Duhok city in Iraq. The building was designed in 2010 using the ACI 3182002 code. The building is an eightstory RC building and is $26.9 \mathrm{~m}$ in. The first storey of the building is $4.5 \mathrm{~m}$ clear height and all other storeys are $3.2 \mathrm{~m}$ in height, which cause irregularity in vertical direction as shown in figure 2. The plan dimensions of the structure are $20 \mathrm{~m}$ (north-south dimension) by $26.6 \mathrm{~m}$ (east-west dimension) as illustrated in figure 5 . The existing structure was designed in accordance with the ACI 3182002 code. The structural system consists of moment-resisting frames represented by the columns, beams and slabs.

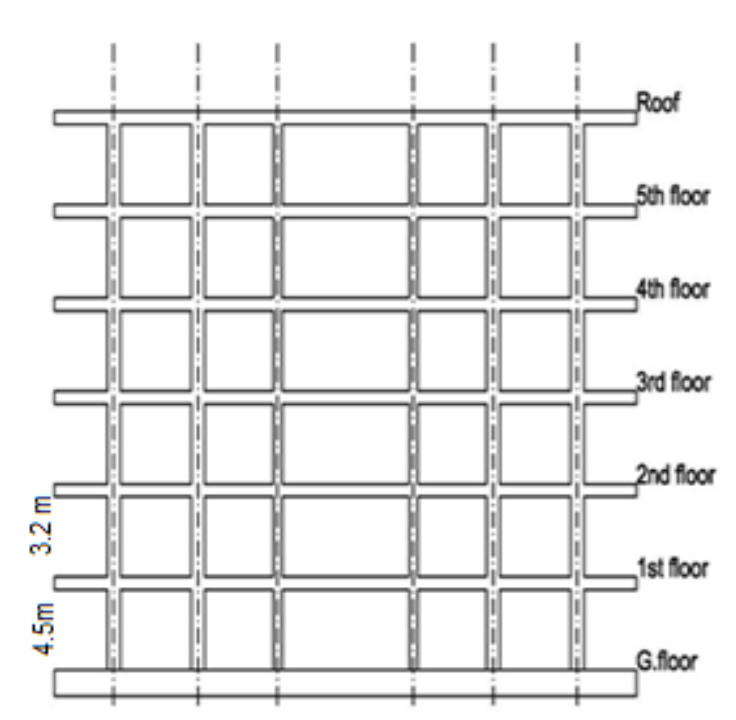

Fig. (2): Elevation View
Fig. (3): Typical longitudinal spandrel beam elevation (existing buildings) 


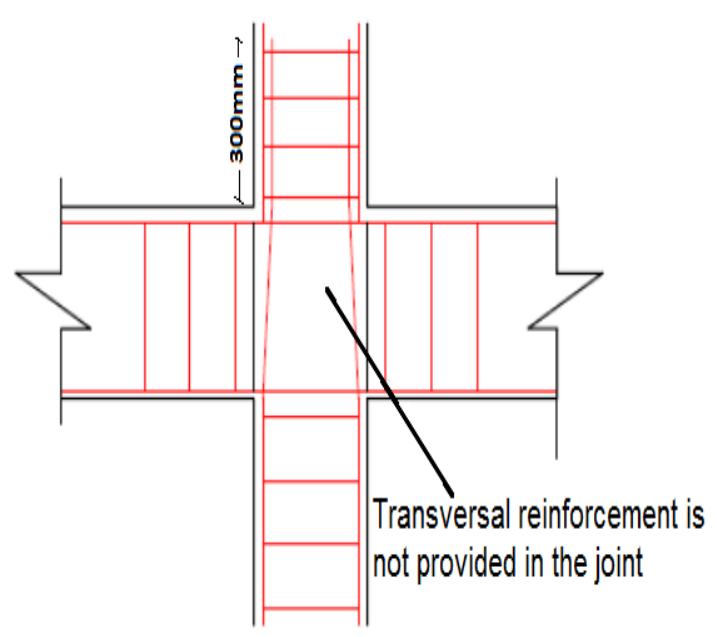

a. existing building

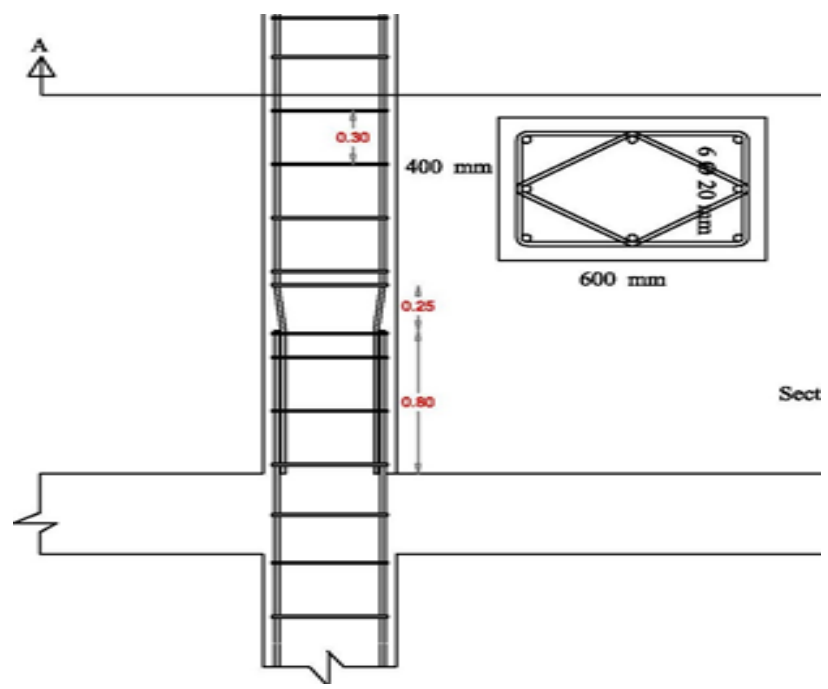

b. redesigned building

Fig. (4): Typical column-beam intersection

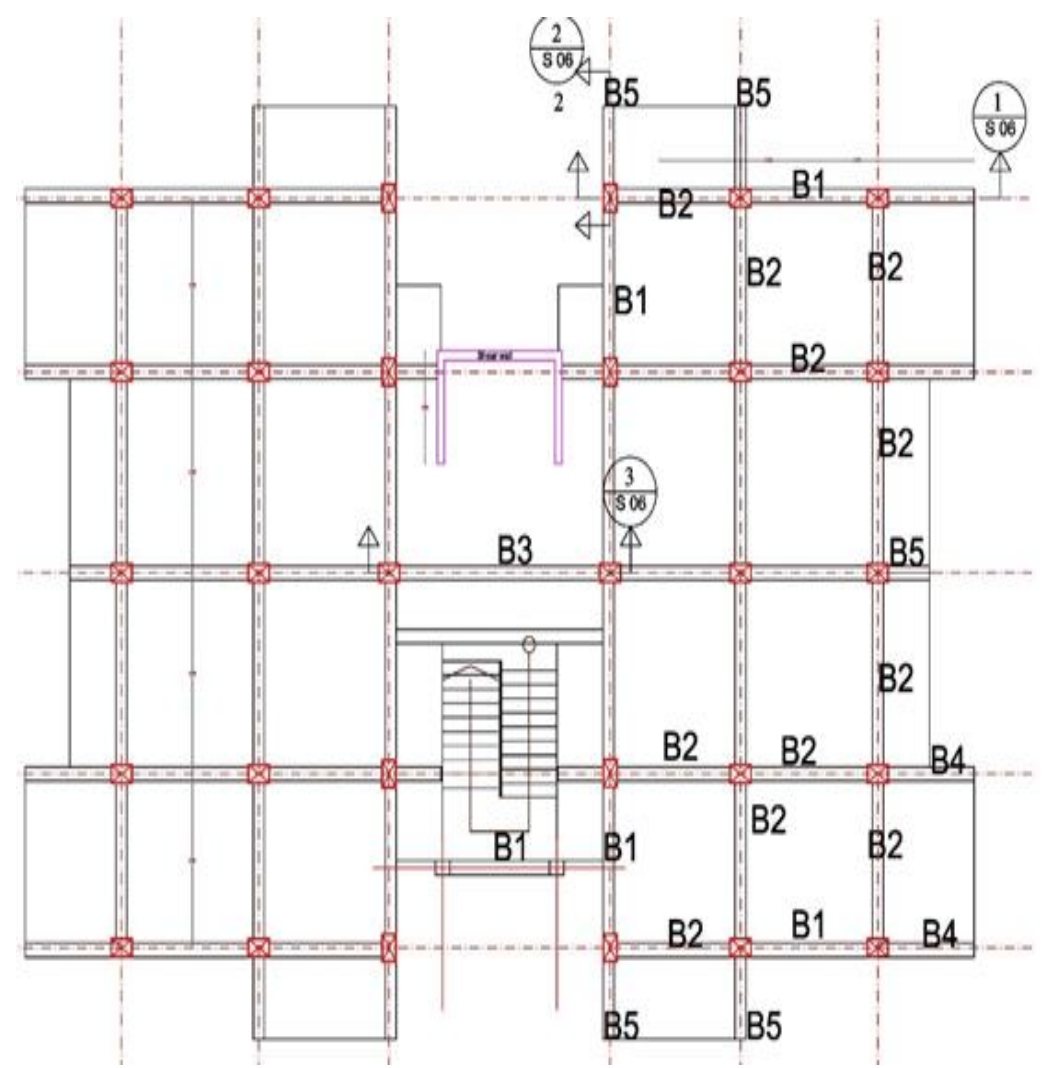

Fig. (5): Floor plan view

\subsection{Redesigned building}

The structure was redesigned in accordance with the ACI 3182014 code and moderate seismic zone was adopted to assess its design and reinforcement detailing. This can expose the hidden weaknesses that cannot be exposed by theoretical analysis. Weaknesses such as inadequate steel bar development specially near the supports, improper column splices position, and poor transverse reinforcement detailing. This can cause a building with poor detailing as illustrated in figure 3 and 4 . This results in inadequate buildings not only for earthquake activity but also for gravity load criteria. Furthermore, A 3-D model has been developed using the ETABS 9.7 software, in order to analyse the applied loads that include gravity load and lateral load including wind load and mand.askar@edu.dpu.krd, kabdouka@swin.edu.au, lawend.kamal@dpu.edu.krd

${ }^{1}$ Corresponding author: ${ }^{1}$ Technical College of Engineering, Duhok Polytechnic University, 

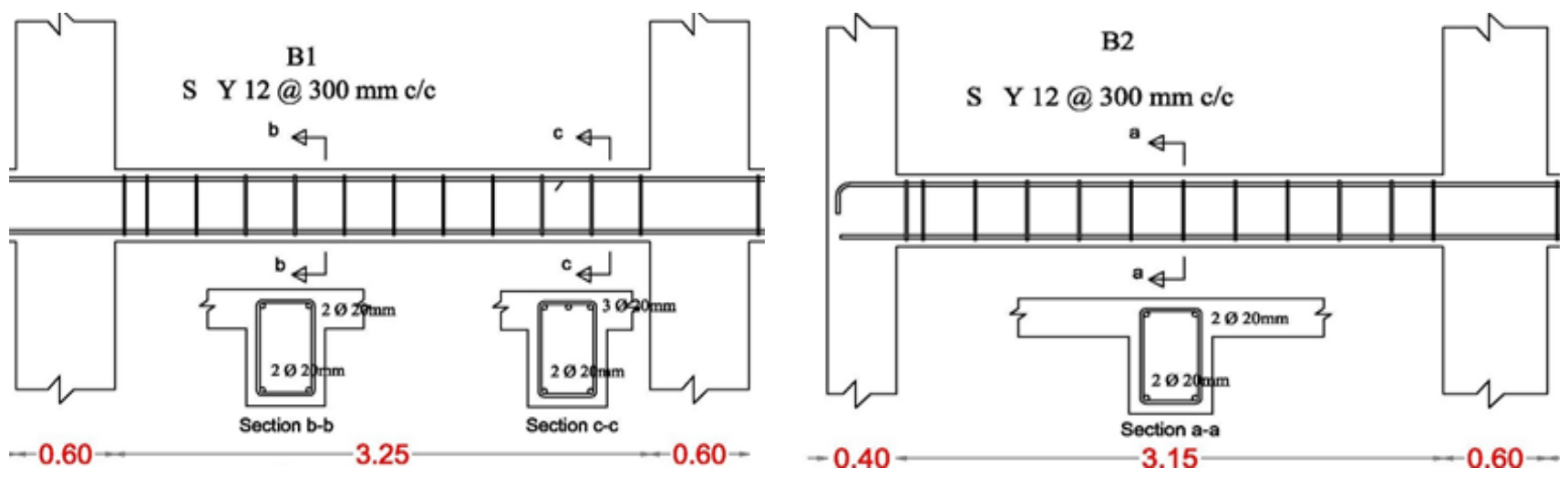

B3
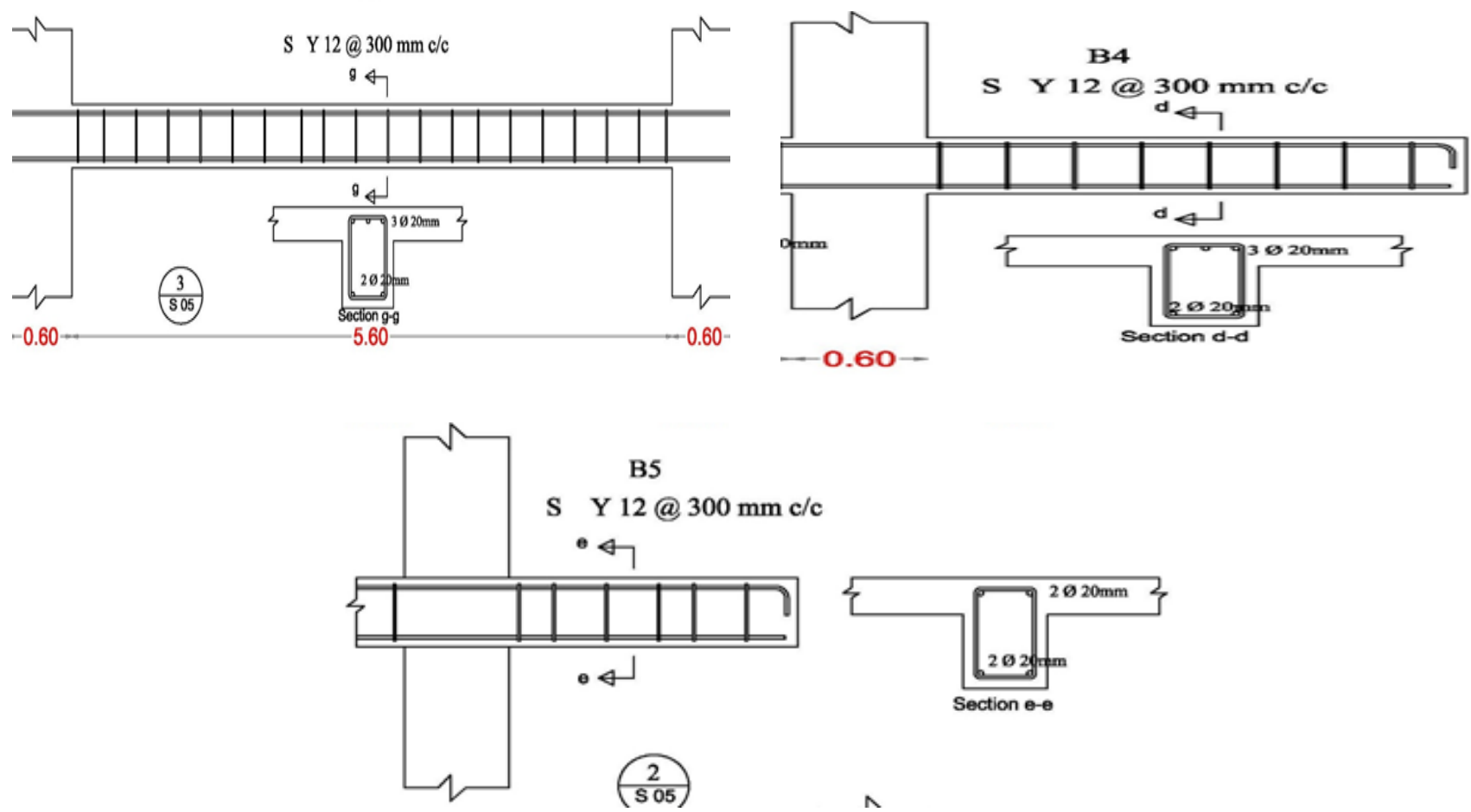

Fig. (6): Beam detailing (Redesigned building)

4. COMPARISON OF STRUCTURAL DESIGNS AND DETAILING OF THE EXISTING BUILDINGS AND THE REDESIGNED BUILDINGS.

\subsection{Inadequate Reinforced Design}

According to the details of the redesigned buildings and reinforcement ratio of the elements, the original design is over reinforced. As it can be seen in Table 1, beams and columns are over reinforced in accordance with the ACI 3182005 code requirement for gravity load design. On the other hand, the slab and foundation reinforcement is inadequate and less than the minimum code requirement. As a result, the existing building is inadequate in terms of reinforcement ratio. Tables 2 and 3 indicate the steel provided for the existing and redesigned buildings respectively. 
Table (1): Comparison in reinforcement ratio between the existing design buildings and the redesigned buildings

\begin{tabular}{|l|c|c|c|}
\hline $\begin{array}{l}\text { Buildings } \\
\text { Members }\end{array}$ & $\begin{array}{l}\text { Reinforcement Ratio } \\
\text { (Existing Buildings) } \\
\text { (Ast/Ag) }\end{array}$ & $\begin{array}{l}\text { Reinforcement ratio } \\
\text { (Redesigned Buildings) } \\
\text { (Ast/Ag) }\end{array}$ & $\begin{array}{l}\text { Reinforcement ratio of the } \\
\text { redesigned RC buildings over } \\
\text { the existing design \% }\end{array}$ \\
\hline B1 & 0.012 & 0.0093 & 77.5 \\
\hline B2 & 0.015 & 0.0093 & 62 \\
\hline B3 & 0.026 & 0.011 & 42.3 \\
\hline B4 & 0.012 & 0.011 & 91.6 \\
\hline B5 & 0.01 & 0.0093 & 93 \\
\hline Column & 0.0106 & 0.0105 & 99 \\
\hline Slab Reo & 0.0025 & 0.0035 & 140 \\
\hline Raft footing & 0.0025 & 0.004 & 160 \\
\hline
\end{tabular}

Table (2): Beams reinforcement details (existing building)

\begin{tabular}{|c|c|c|c|c|}
\hline Beams ID & $\begin{array}{c}\text { Top } \\
\text { Reinforcement }\end{array}$ & $\begin{array}{c}\text { Bottom } \\
\text { Reinforcement }\end{array}$ & $\begin{array}{c}\text { Mid-section } \\
\text { Reinforcement }\end{array}$ & $\begin{array}{c}\text { Transversal } \\
\text { Reinforcement Spacing }\end{array}$ \\
\hline B1 & 4 Y16 & $4 Y 16$ & $2 Y 16$ & Y12@300 mm \\
\hline B2 & $5 Y 16$ & $5 Y 16$ & - & Y12@300 mm \\
\hline B3 & 4 Y16, 3Y20 & $4 Y 16,3 Y 20$ & - & Y12@300 mm \\
\hline B4 & $5 Y 16$ & 3Y16 & 2Y16 & Y12@300 mm \\
\hline B5 & $4 Y 16$ & 3Y16 & 2Y16 & Y12@300 mm \\
\hline
\end{tabular}

Table (3): Beams reinforcement details (redesigned building)

\begin{tabular}{|c|c|c|c|}
\hline Beams ID & Top Reinforcement & Bottom Reinforcement & $\begin{array}{c}\text { Transversal } \\
\text { Reinforcement Spacing }\end{array}$ \\
\hline B1 & 2 Y20 & 2 Y20 & Y12@300 mm \\
\hline B2 & 2 Y20 & 2 Y20 & Y12@300 mm \\
\hline B3 & 3 Y20 & 2 Y20 & Y12@300 mm \\
\hline B4 & 3 Y20 & 2Y20 & Y12@300 mm \\
\hline B5 & 2 Y20 & 2Y20 & Y12@300 mm \\
\hline
\end{tabular}

\subsection{Inadequacies in Detailing}

Both case study buildings show inadequate reinforcement detailing represented by both reinforcement distribution and anchorage of transverse reinforcement. These typical deficiencies in detailing often result in local damage and collapse modes. This issue reflects the problem that RC buildings in the Kurdistan region suffer from.

\subsection{Column Lap Splices}

The design of the existing case study building was governed primarily by gravity loading and mand.askar@edu.dpu.krd, kabdouka@swin.edu.au, lawend.kamal@dpu.edu.krd

${ }^{1}$ Corresponding author: ${ }^{1}$ Technical College of Engineering, Duhok Polytechnic University,

Duhok- Kurdistan Region the column detailing is very poor. Despite the fact that the ACI 318-2014 suggests the lap splice length should not be less than the largest of $300 \mathrm{~mm}$ and $48 \mathrm{~d}_{\mathrm{b}}$, in both existing buildings the lap splices length is approximately $300 \mathrm{~mm}$ (Figure 4), which is less than the code minimum requirement length. Moreover, the transverse steel reinforcement along the splice length is not provided. This is not appropriate practice especially when the column is designed for resisting lateral loads. In fact, this practice makes the column work to resist compression 
loads and weakens the lateral capacity of the column. Moreover, the splices in the columns in the case study buildings are located just above the slab at each floor level. Thus, the column splicing would be deemed inadequate by today's standards. One would expect limited tensile capacity and limited ductility (SARKAR S. 2013), (LEE 2013).

\subsection{Beam-Column Joints}

The forces between columns and beams are transferred by the beam-column joints. Therefore, to develop the full capacity of the frame members, adequate strength of the joint is essential. Joints have to have transverse reinforcement to provide better behaviour during seismic activity. The case study buildings had essentially no transverse joint reinforcement (Figure 4-a). Under severe earthquake activity, insufficient transverse reinforcement can lead to shear failure of the joints due to the loss of bond capacity within the joint. According to (WALKER, S. G 2001), such damage has been observed in laboratory test of joints with no transverse reinforcement.

\subsection{Beam Bar Anchorage}

Bottom reinforcement in the beams is placed to provide positive moment resistance, especially at mid-span. Therefore, in this case study building the steel reinforcement is not extend to the support or even to the column face (Figure 3). Lateral forces generated by an earthquake cause negative moment at the bottom of some beams at supports. Therefore, proper detailing should allow for a full development of reinforcement bars at the bottom of the beam at the supports. Hence, these inadequate detailing results in reducing the moment capacity of the beam during an earthquake. According to (ACI 318 2014), top bar reinforcement should be extended beyond the point where it is no longer required to resist flexure for a distance equals to the greatest of D or $12 \mathrm{db}$. However, in the case study building (Figure 3), the top bars of the beams are extended $280 \mathrm{~mm}$ into the joint, while the required length is $450 \mathrm{~mm}$. Bottom bar detailing was simulated using the SeismoStruct software trying to achieve the real behaviour of the existing buildings. This is by multiply the ratio in the software, the ratio obtained by dividing the actual length of development on the required length, by the actual quantity of the reinforcement at the supports as illustrated in Equation (1). This means that the poor detailing of the beam bar anchorage in the existing case study building affected the overall behaviour during pushover analysis (RAJU, K 2012).

\section{Reinforcement ration $=$ $\frac{L \text { Actual development }}{\text { L Required development }} x$ Actual reo quantity} (1)

\section{SIMULATION ENVIRONMENT}

The existing and redesigned structures have been evaluated using nonlinear static pushover analysis. SeismoStruct V6.5 software analysis is used for this purpose using capacity spectrum, and displacement coefficient methods. Capacity curves were generated for the two buildings by pushing the top node of each structure to the target displacement and setting appropriate performance criteria such as shear limit, moment curvature limit, concrete cracking and cover spalling for the elements using ExpressStructure software (MONAVARI B. 2012).

\subsection{Target Displacement}

The target displacement for the structure is derived by linearization of the obtained pushover curve and subsequent use of Displacement Coefficient Method according to ASCE 41-06 standard. However, the fundamental period of a building is not given by this standard, therefore the Iraqi Seismic Code 1997 was used to find T, which will be used later to find the effective fundamental period $\mathrm{T}_{\mathrm{e}}$. Based on calculations in accordance with ASCE 41-06 standard, the pushover curve for existing structure was loaded for a displacement of $150 \%$ of $\delta \mathrm{t}$ equal to $39.5 \mathrm{~mm}$ at the top node for $\mathrm{x}$-axis loading and $35.6 \mathrm{~mm}$ for $y$-axis loading. 


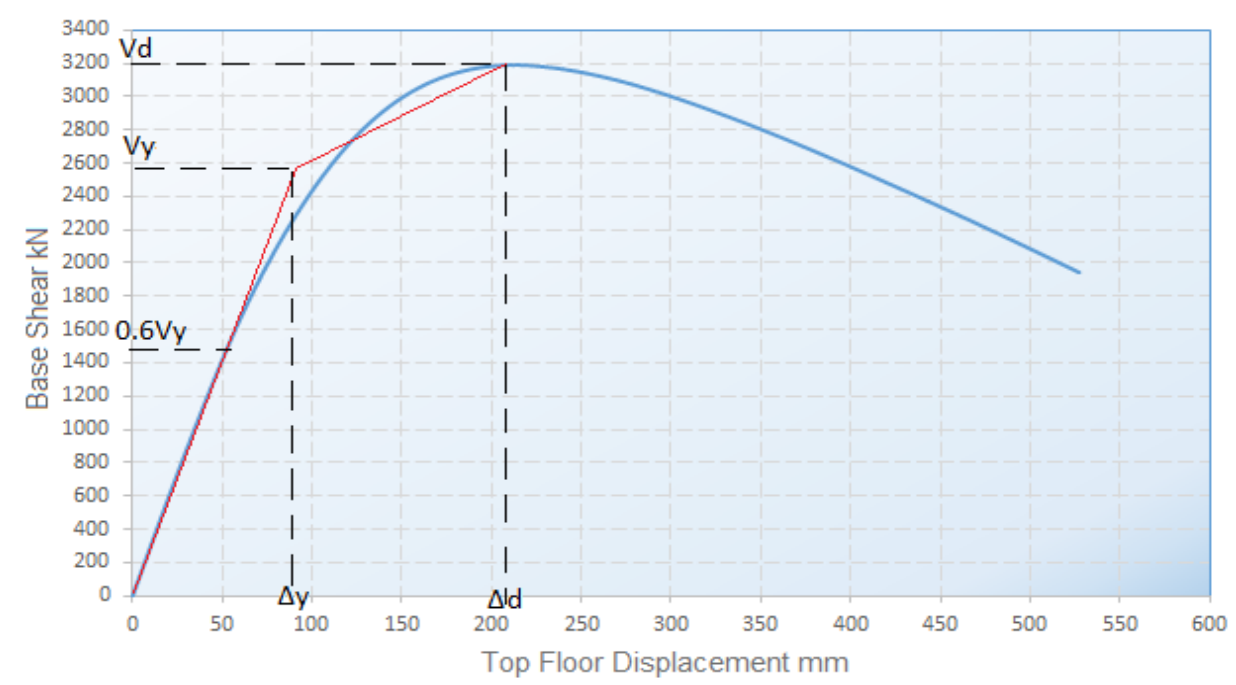

Fig. (7): Idealized pushover curve for the existing building: x-axis loading loading.

Redesigned building was loaded to $39 \mathrm{~mm}$ at the top node for $\mathrm{x}$-axis loading and equal to $35.1 \mathrm{~mm}$ for $\mathrm{y}$-axis

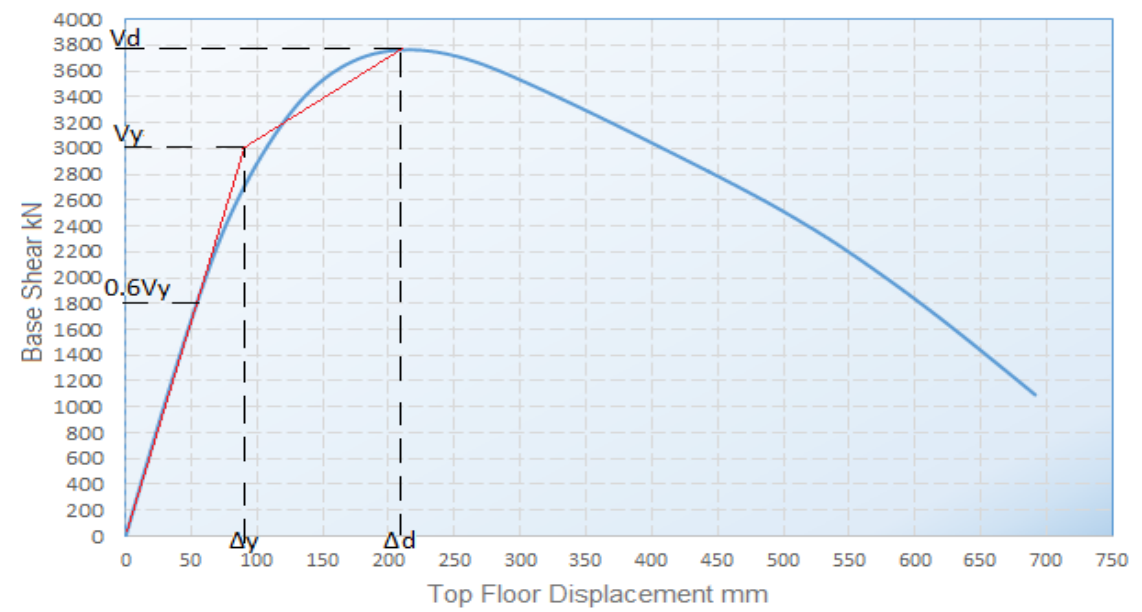

Fig. (8): Idealized pushover curve for the redesigned 8-storey building: x-axis loading

The analysis is then carried out for $150 \%$ of the calculated target displacement for the structure to observe the yielding of the members and the adequacy of the structural strength. The extent of damage experienced by the structure at the target displacement is considered to represent the damage that would be experienced by the building when subjected to a design earthquake.

\subsection{Base Shear}

Base shear for the existing and redesign buildings in accordance with AS 1170.4-2007 was $1980 \mathrm{KN}$. Then the structures are loaded in both $\mathrm{x}$ and $y$ directions until their limit (Figure 9).

mand.askar@edu.dpu.krd, kabdouka@swin.edu.au, lawend.kamal@dpu.edu.krd ${ }^{1}$ Corresponding author: ${ }^{1}$ Technical College of Engineering, Duhok Polytechnic University, 

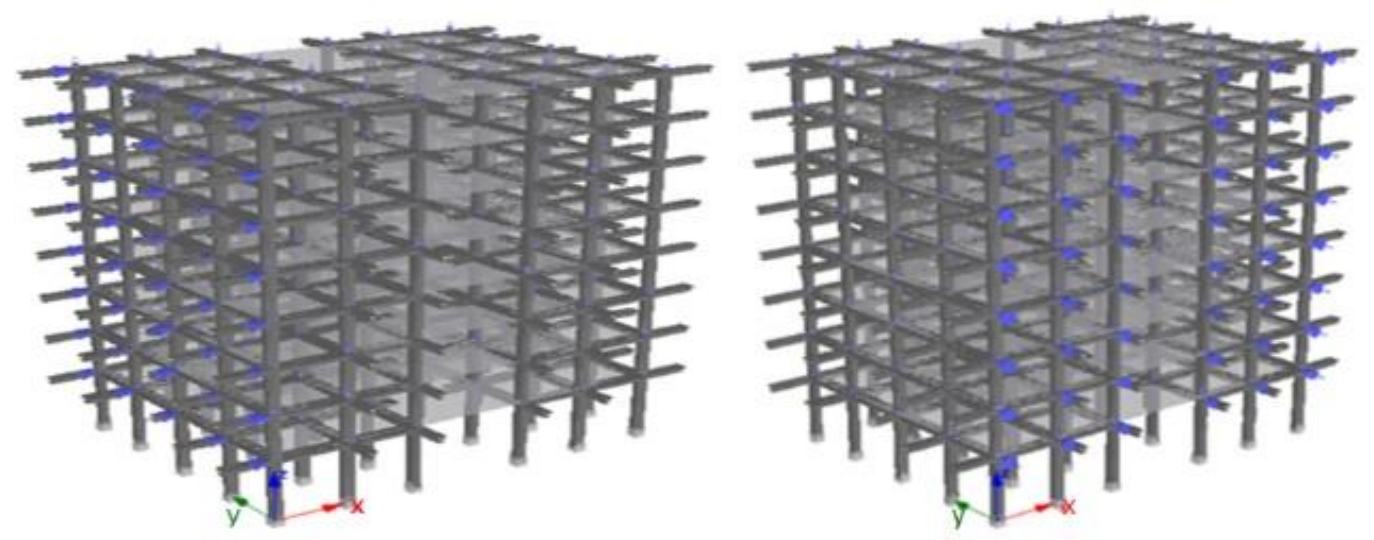

Fig. (9): Pushover loadings for $\mathrm{x}$ and $\mathrm{y}$-axis

\subsection{Reinforcement Detailing Simulation}

The poor detailing of the existing two case study RC buildings was simulated by adjusting the ratio of reinforcement at the supports. This is done by looking at the length of development of the beams at the supports. This criterion has been investigated because the current practice in the Kurdistan region is to stop the bottom bars of the beam near the support as the bottom reinforcement is required by the code in the middle of the spans only. However, during an earthquake, due to the lateral loads generated by seismicity, negative moment at the bottom of some beams can be generated at the support especially at the end spans. For this reason, length of development for the reinforcement in the existing two case study buildings investigated and compared with the required length of development. By dividing the actual length of development on the required length, we will have the ratio of the effective reinforcement at the supports. Then by multiply this ratio by the actual quantity of the reinforcement at the supports, we can get the simulated reinforcement quantity for the existing two case study buildings at the supports. By this, the detailing of the existing buildings can be simulated using a software model (MOUZZOUN M 2013).

\subsection{Performance Criteria}

Inclusion of shear failure limits, moment curvature limits, and cover spalling for the sections is essential to identify the behaviour of the buildings during the pushover analysis using the SismoStruct version 9.5 software. Therefore, moment curvature of the sections based on ASCE 41-06 standard were obtained using StructureExpress version 6.5 software. The analysis of this software is based on strain compatibility approach. A Series of moment curvature graphs are illustrated below that represent the idolized sections moment curvature of buildings' elements. The ultimate value then was used in SeisoStruct software to set the section moment curvature limits in the program. Shear failure limit in the program is also set using mathematical approached and shear capacity of all elements were calculated.

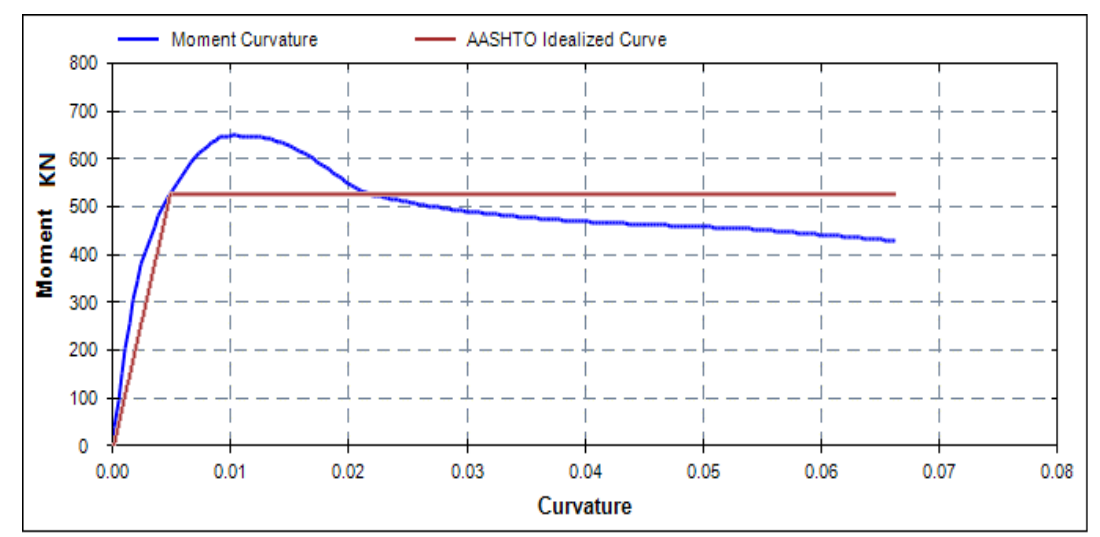

Fig. (10): Moment curvature of existing columns

mand.askar@edu.dpu.krd, kabdouka@swin.edu.au, lawend.kamal@dpu.edu.krd

$124{ }^{1}$ Corresponding author: ${ }^{1}$ Technical College of Engineering, Duhok Polytechnic University,

Duhok- Kurdistan Region 


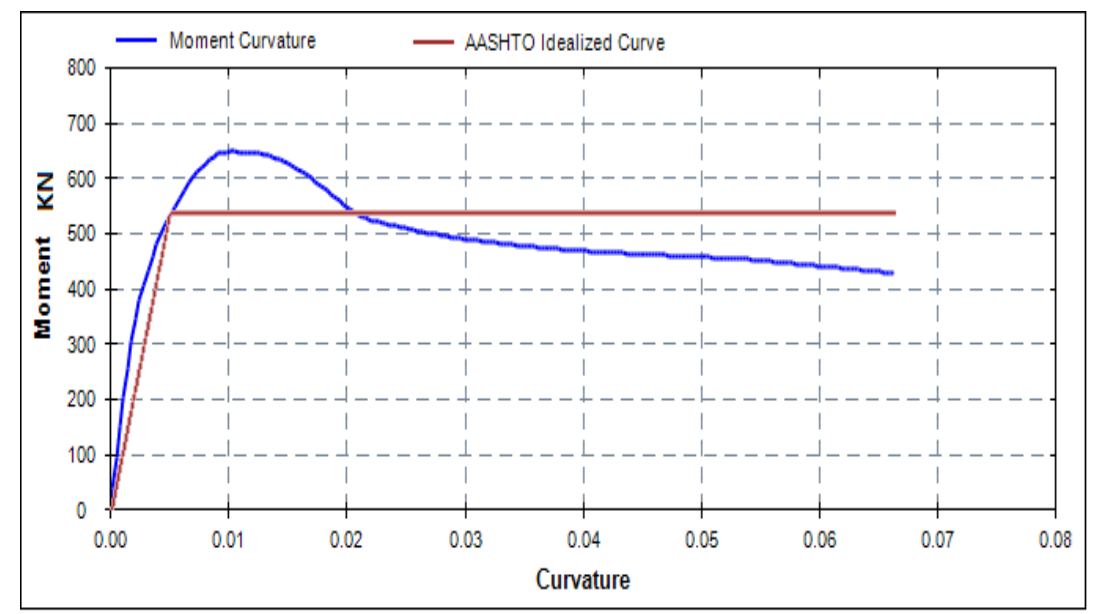

Fig. (11): Moment curvature of redesigned columns

\section{RESULTS}

The pushover analysis is undertaken by loading the structure to a state of complete collapse and a capacity curve is obtained using SeismoStuct Version 9.5. The structure is then pushed to the code calculated base shear for limiting displacement. Taking into account the low level of seismicity of the site location and the characteristic features of the structure and using ASCE 41-06, with adopting moderate seismic region, the target displacement is calculated and then used in SeismoStruct software for both $\mathrm{x}$-axis loading and $\mathrm{y}$-axis loading to generate pushover curves by pushing the building to the target displacement under the considered direction. Then the generated curves were integrated in the actual pushover curves of the buildings. There was both concrete cracking and some cover spalling, which identified by the SeismoStruct software, in some elements when the models were loaded, but the overall behaviour of the models was safe. However, the design detailing assessment of the buildings shows that the reinforcement detailing of the existing buildings has major inadequacies in terms of bottom beam bar anchorage, splices lap, and beam-column connection. These inadequacies can affect the overall behaviour of a building and reduce ductility.

The existing 8-story building reached failure at $525 \mathrm{~mm}$ during $\mathrm{x}$-axis loading, and the ultimate base shear was $3200 \mathrm{kN}$ with $200 \mathrm{~mm}$ displacement (Figure 12). When loaded at yaxis, the building reached failure at $255 \mathrm{~mm}$, and the ultimate base shear was $3500 \mathrm{kN}$ with $225 \mathrm{~mm}$ displacement (Figure 13). While the redesigned 8 -story building reached failure at $690 \mathrm{~mm}$ during $\mathrm{x}$-axis loading, and the ultimate base shear was $3790 \mathrm{kN}$ with $225 \mathrm{~mm}$ displacement (Figure 12). When loaded at yaxis, the building reached failure at $290 \mathrm{~mm}$, and the ultimate base shear was $3610 \mathrm{kN}$ with $225 \mathrm{~mm}$ displacement (Figure 13).

The base shear value of the building due to the calculated target displacement was $1137 \mathrm{kN}$, which is about $30 \%$ of the base shear capacity of the building, and it was $1090 \mathrm{kN}$ when loaded in $\mathrm{y}$-direction, which is about $31 \%$ of the base shear capacity of the building. On the other hand, the base shear value of the redesigned building due to the calculated target displacement was $1325 \mathrm{kN}$, which is about $35 \%$ of the base shear capacity of the building, and it was $1150 \mathrm{kN}$ when loaded in y-direction, which is about $31 \%$ of the base shear capacity of the building.

In terms of structure capacity, when structures loaded in $\mathrm{x}$-direction, ultimate base shear of the redesigned structure was about $20 \%$ higher than the existing structure when loaded in $\mathrm{x}$-direction and top displacement was $225 \mathrm{~mm}$ which is about $12.5 \%$ higher than displacement in existing structure. 


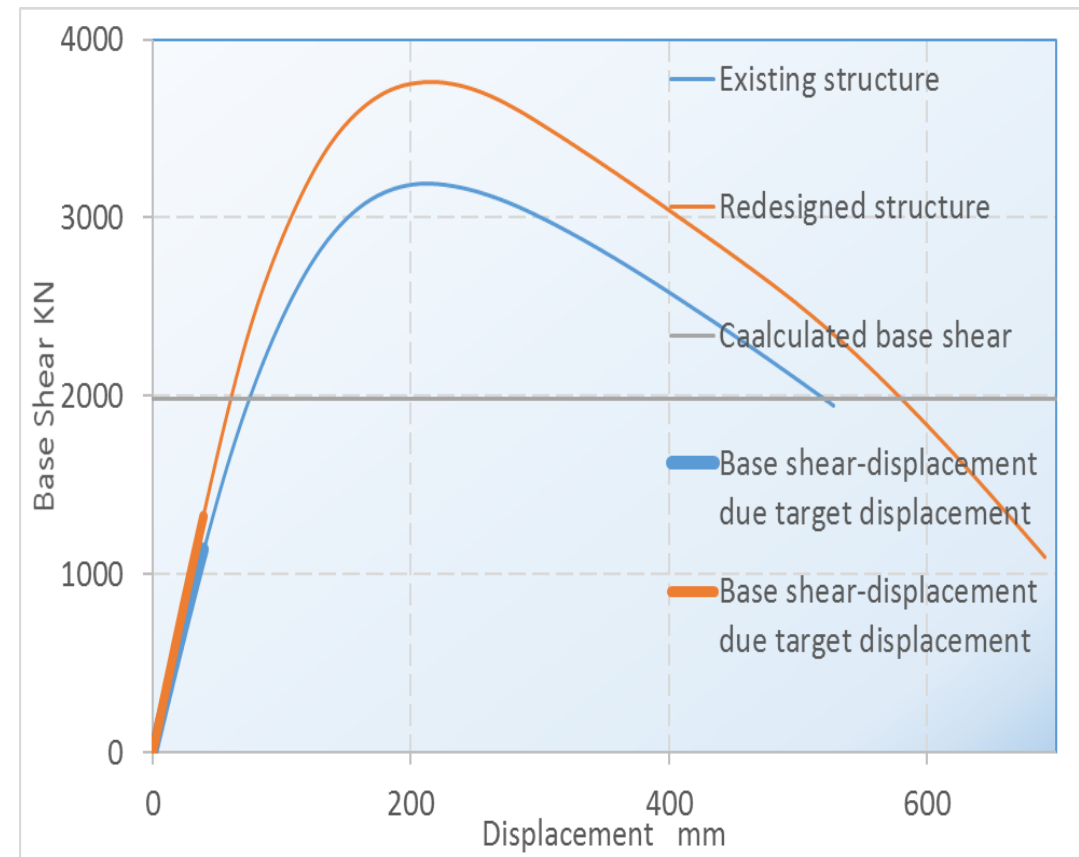

Fig. (12): Base shear and code calculated base shear versus displacement for existing and redesigned structures (x-axis loading)

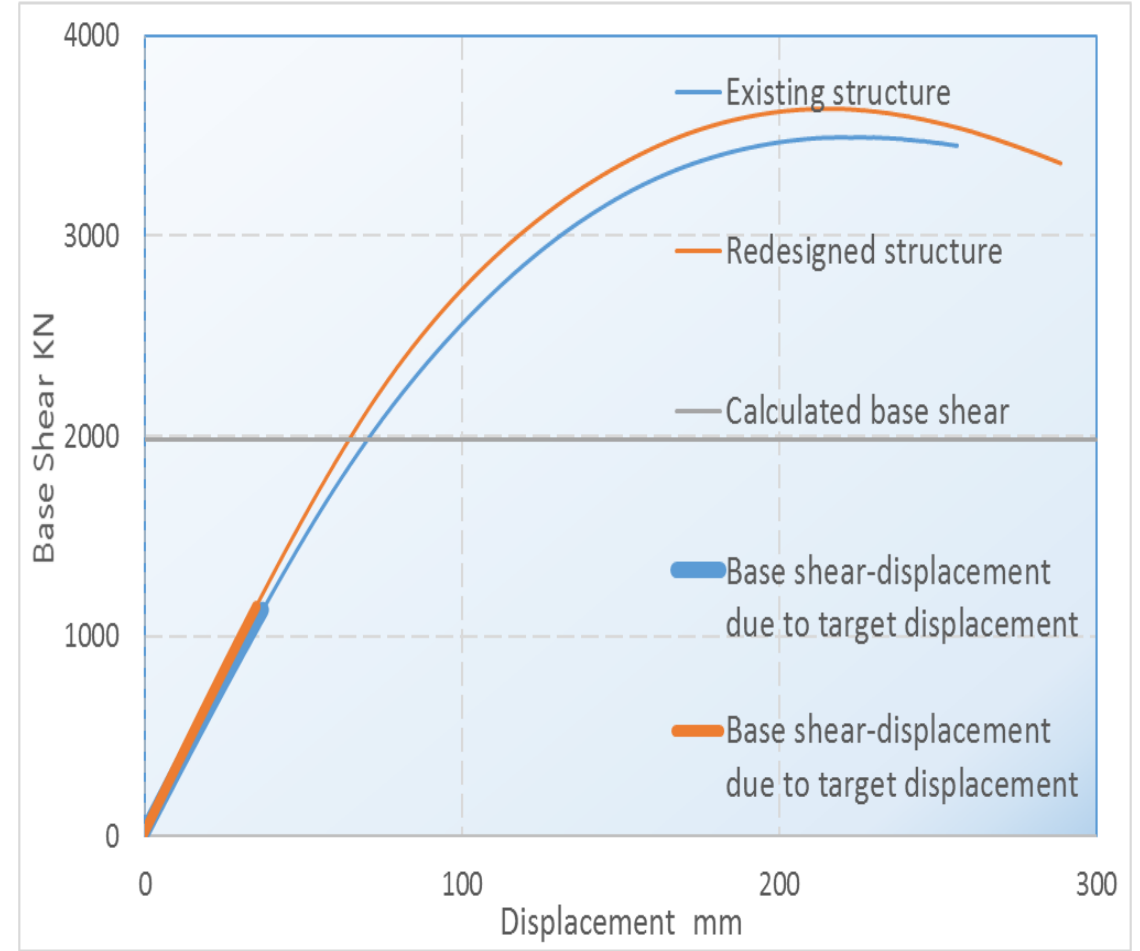

Fig. (13): Base shear and code calculated base shear versus displacement for existing and redesigned structures (y-axis loading)

Inter storey drift versus base shear and code calculated base shear for both structures were obtained as damage indicator base on capacity curve.

inter-storey drift for level $i=\frac{\Delta_{i 2}-\Delta_{i 1}}{h}$, where, $\Delta_{i 2}$, and $\Delta_{i 1}$ are the displacement of the top floor and the displacement of the bottom floor respectively. $\mathrm{h}$ is the height of the considered floor. 


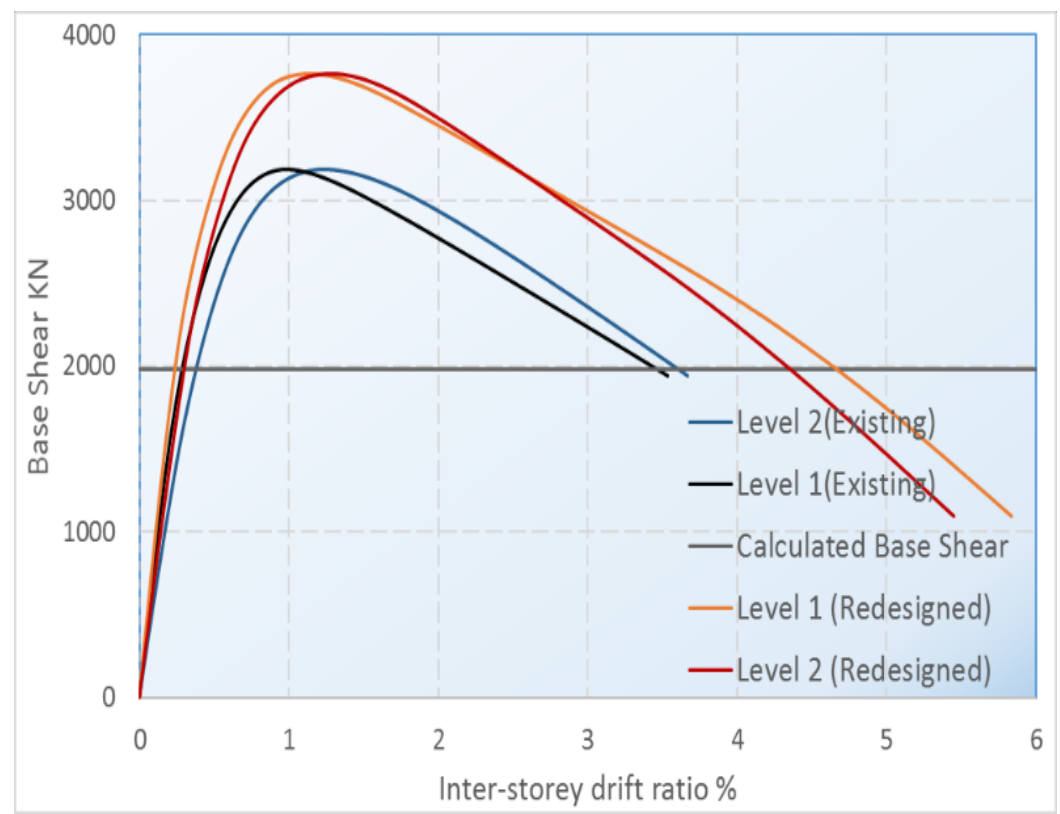

Fig. (14): Inter-story Drift versus Base Shear Plot for first two storeys upon $x$-axis loading for existing and redesigned structures

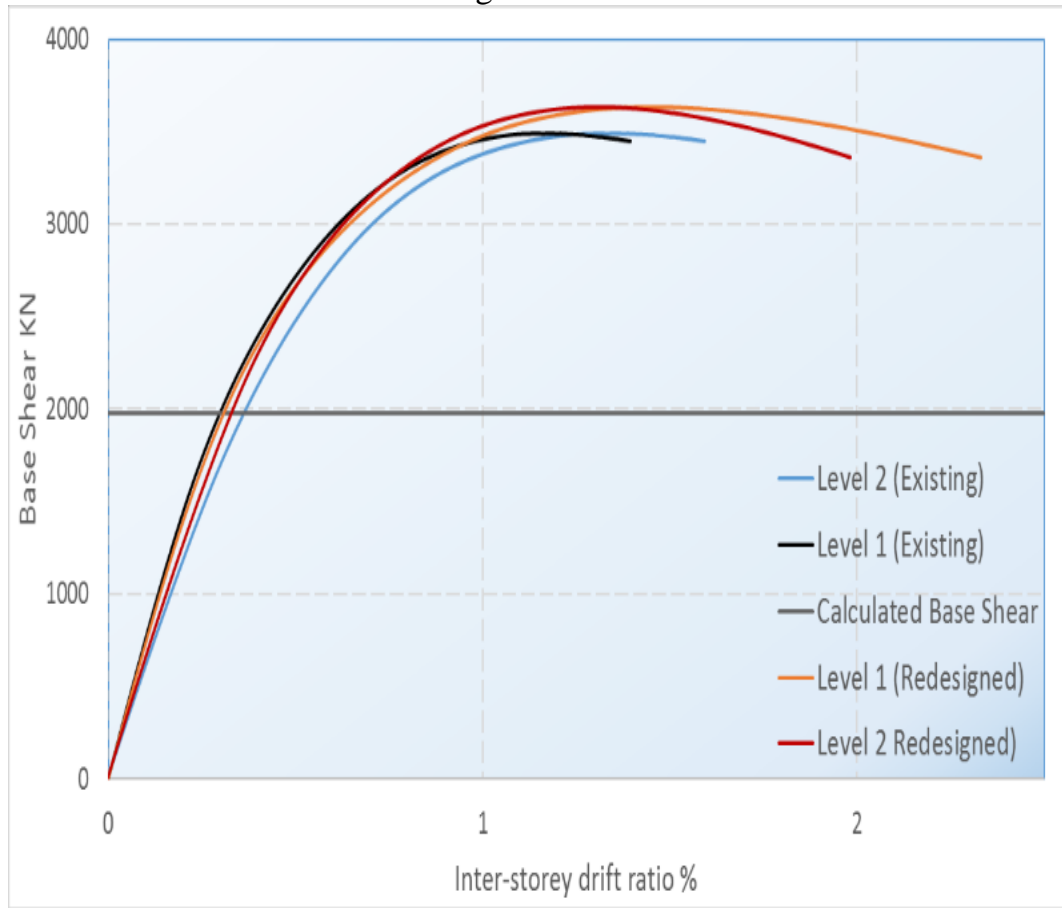

Fig. (15): Inter-story Drift versus Base Shear Plot for first two storeys upon y-axis loading for existing and redesigned structures

The obtained inter-story drift versus base shear curves indicates that the redesigned structure shows improved $\mathrm{b}$ behaviour under applied base shear when the structure loaded in $\mathrm{x}$-direction. This leads in ductility enhancement.

mand.askar@edu.dpu.krd, kabdouka@swin.edu.au, lawend.kamal@dpu.edu.krd 


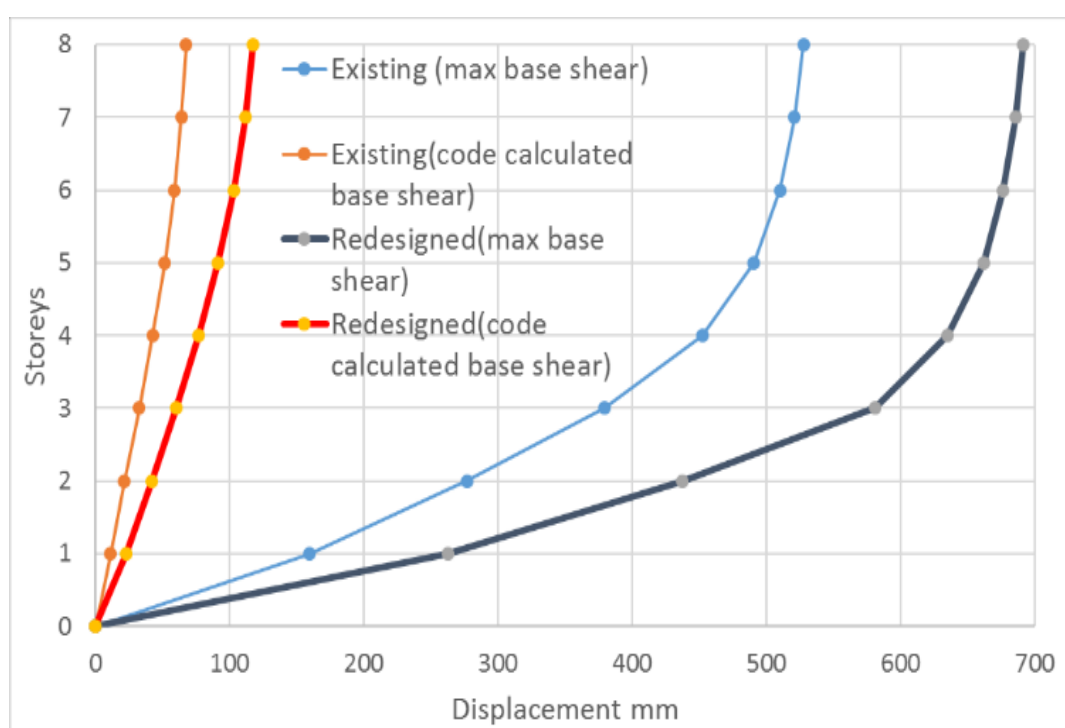

Fig. (16): Building displacement versus code calculated and ultimate base shear Plots upon $\mathrm{x}$-axis loading for existing and redesigned structures

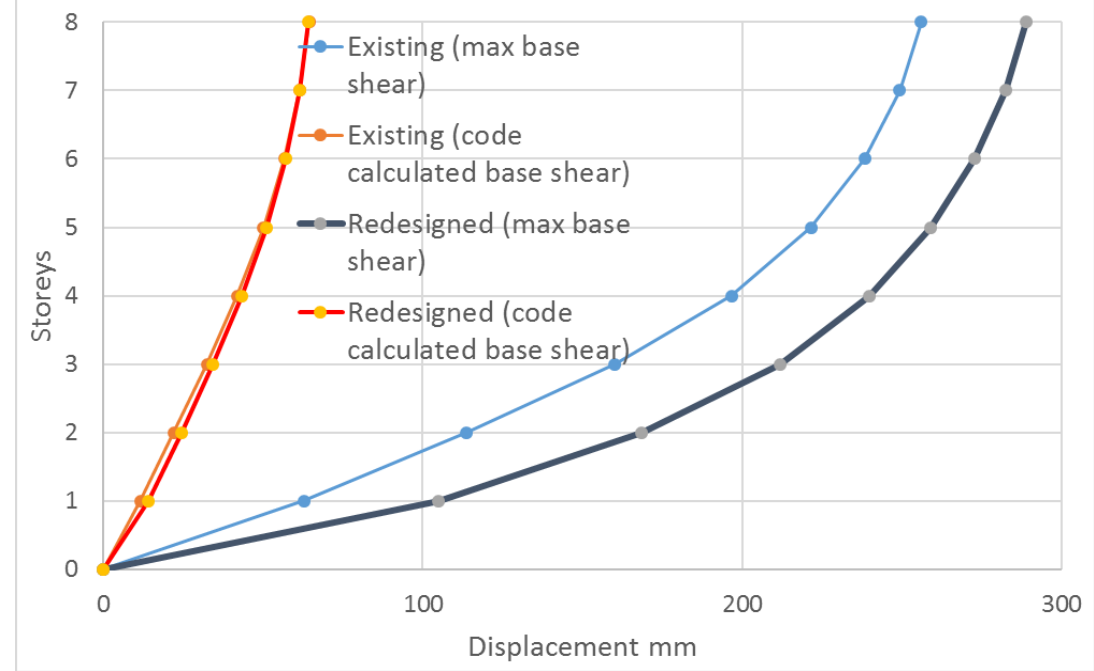

Fig. (17): Building displacement versus code calculated and ultimate base shear Plots upon y-axis loading for existing and redesigned structures

Building displacement is a significant factor for assessing the seismic behaviour of a building. In the analysed models the building displacement versus base shear curves obtained from the pushover analysis, indicates that the total displacement of the buildings reached the allowable displacement limit $(\Delta=2 \%$ of the building height). When structure loaded in $\mathrm{x}$ direction, displacement in the existing 8-story building was $525 \mathrm{~mm}$ based on ultimate base shear and $75 \mathrm{~mm}$ based on calculated base shear. Redesigned structure behave differently, displacement was $690 \mathrm{~mm}$ based on ultimate base shear and $120 \mathrm{~mm}$ based on calculated base shear. Where the existing structure loaded in ydirection, displacement was $255 \mathrm{~mm}$ based on ultimate base shear and $65 \mathrm{~mm}$ based on calculated base shear. Redesigned structure showed more ductility as displacement was $290 \mathrm{~mm}$ based on ultimate base shear and $67 \mathrm{~mm}$ based on calculated base shear. Furthermore, inter storey drift data for the redesigned building showed improved ductility in existing building specifically when loaded in $\mathrm{x}$-direction. As a result, redesigned structure shows more ductility than existing structure as the displacement was increased about 35\% in each floor level for both maximum and target displacement compared

mand.askar@edu.dpu.krd, kabdouka@swin.edu.au, lawend.kamal@dpu.edu.krd

${ }^{1}$ Corresponding author: ${ }^{1}$ Technical College of Engineering, Duhok Polytechnic University,

Duhok- Kurdistan Region 
with existing structure when loaded in $\mathrm{x}$ direction under ultimate base shear while was around $10 \%$ when loaded in y-direction.

\section{CONCLUSIONS}

The existing and redesigned buildings, did not incur any major failure in relation to the pushover analysis based on the target displacement and the behaviour of the buildings due to the target displacement was safe. The pushover analysis reveals some significant facts. It clearly indicates that whilst reinforcement quantity is important, detailing is just as essential. According to the detailing of the existing structure, reinforcement was about $25 \%$ more than the redesigned one, and there was inappropriate detailing of beam bar anchorage at the supports, joint without transversal reinforcement, and inappropriate location for column splices. Hence, poor detailing of the existing buildings reduces the effectiveness of the reinforcement used. The additional reinforcement is not only ineffective but an unnecessary cost. Moreover, the redesigned structure showed increasing in ductility as displacement increased about 30\% compared with existing structure when loaded in $\mathrm{x}$ direction based on both ultimate and calculated base shear and about 10\% increased when loaded in y-direction which lead in better seismicity behaviour. Base shear capacity is also further increased with improving in inter-story drift behaviour.

\section{REFERENCES}

EL-KHOLY, S., EL-ASSALY, M. \& MAHER, M. 2012. Seismic Vulnerability Assessment of Existing Multi-Story Reinforced Concrete Buildings in Egypt. Arabian Journal for Science \& Engineering (Springer Science \& Business Media B.V. ), 37, 341-355.

Castaldo, P., Palazzo, B., and Ferrentino, T. (2017) Seismic reliability- based ductility demand evaluation for inelastic base-isolated
structures with
devices. Earthquake
friction pendulum Engng Struct. Dyn., 46: 1245-1266. doi: 10.1002/eqe.2854.

KRAWINKLER, H. \& SENEVIRATNA, G. 1998. Pros and cons of a pushover analysis of seismic performance evaluation. Engineering structures, 20, 452-464.

MWAFY, A. \& ELNASHAI, A. 2001. Static pushover versus dynamic collapse analysis of RC buildings. Engineering structures, 23, 407424.

AHMED, S. Y. 2013. Seismic Evaluation of Reinforced Concrete Frames Using Pushover Analysis. Al-Rafadain Engineering Journal, $21,28-45$.

MASI, A. \& VONA, M. 2012. Vulnerability assessment of gravity-load designed RC buildings: Evaluation of seismic capacity through non-linear dynamic analyses. Engineering Structures, 45, 257-269.

REPAPIS, C., ZERIS, C. \& VINTZILEOU, E. 2006. EVALUATION OF THE SEISMIC PERFORMANCE OF EXISTING RC BUILDINGS II:: A CASE STUDY FOR REGULAR AND IRREGULAR BUILDINGS. Journal of Earthquake Engineering, 10, 429-452.

ATHANASSIADOU, C. 2008. Seismic performance of $\mathrm{R} / \mathrm{C}$ plane frames irregular in elevation. Engineering structures, 30, 1250-1261.

RAJEEV, P. \& TESFAMARIAM, S. 2012. Seismic fragilities for reinforced concrete buildings with consideration of irregularities. Structural Safety, 39, 1-13.

CHINTANAPAKDEE, C. \& CHOPRA, A. K. 2004b. Seismic Response of Vertically Irregular Frames: Response History and Modal Pushover Analyses. Journal of Structural Engineering, 130, 1177-1185.

ASCE 41-06 (2007), Seismic Rehabilitation of the Existing Buildings, American

mand.askar@edu.dpu.krd, kabdouka@swin.edu.au, lawend.kamal@dpu.edu.krd

${ }^{1}$ Corresponding author: ${ }^{1}$ Technical College of Engineering, Duhok Polytechnic University,

Duhok- Kurdistan Region 
SARKAR S. (2013): Seismic Evaluation of 4-Story Reinforced Concrete Structure by Non-Linear Static Pushover Analysis, Bachelor of Technology Thesis, National Institute of Technology Rourkela, Department of Civil Engineering.

LEE, C. S., HAN, S. W. \& KWON, H. W. 2013. Seismic performance evaluation for gravitydesigned flat plate frames. Magazine of Concrete Research, 65, 1110-1127.

WALKER, S. G. (2001). "Seismic performance of existing reinforced concrete beam-column joints", MSCE thesis, Univ. of Washington, Seattle, 250P.

RAJU, K., CINITHA, A. \& IYER, N. 2012. Seismic performance evaluation of existing $\mathrm{RC}$ buildings designed as per past codes of practice. Sadhana, 37, 281-297.

MONAVARI B., MASSUMI A., KAZEM, A (2012): Estimation of Displacement Demand in RC Frames and Comparing with Target
Displacement Provided by FEMA-356, 15th

World Conference on Earthquake

Engineering, 24th to 28th September, 2012,

Lisbon, Portugal.

MOUZZOUN M., Moustachi O., Taleb A., Jalal S. (2013): Seismic performance assessment of reinforced concrete buildings using pushover analysis, IOSR Journal of Mechanical and Civil Engineering (IOSR-JMCE); ISSN: 22781684 Volume 5, Issue 1 (Jan. - Feb. 2013), PP 44-49.

ATC 40," Seismic Evaluation and Retrofit of Concrete Buildings", Applied Technology Council, Redwood City, CA, USA, Report No. SSC 96-01, Vol. 1 \& 2, Nov. 1996.

FEMA 356, Pre-standard and Commentary for the Seismic Rehabilitation of the Buildings, Federal Emergency Management Agency \& American Society of Civil Engineers, November 2000. Centre, 1997.

mand.askar@edu.dpu.krd, kabdouka@swin.edu.au, lawend.kamal@dpu.edu.krd

130 Corresponding author: ${ }^{1}$ Technical College of Engineering, Duhok Polytechnic University,

Duhok- Kurdistan Region 